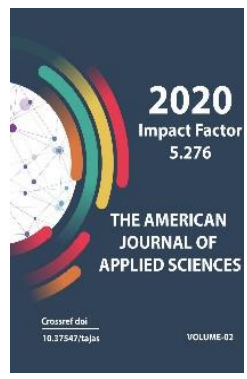

\title{
Reconstruction of 5-storey large panel buildings, use of atmospheric precipitation water for technical purposes in the building
}

\author{
Axmedov Tolkin \\ Senior Lecturer, Department of Construction of Buildings and Structures, Fergana Polytechnic \\ Institute, Fergana, Uzbekistan
}

\section{ABSTRACT}

This article provides basic information on engineering selection and beautification of urban areas where 5-storey residential buildings should be built in response to emergencies in ways to increase the energy efficiency of buildings using atmospheric water for technical purposes.

\section{KEYWORDS}

Attic; residential building; atmospheric precipitation; roofing, parapet.

\section{INTRODUCTION}

1- 72-series 5-story large-panel residential buildings of the construction industry. Introduced in the $65 \mathrm{~s}$ and $70 \mathrm{~s}$ of the last century, these projects are one of the most innovative projects in the Republic of Uzbekistan, and one of the most innovative projects of its kind has been built in the last 20 years. Currently, the buildings of this series make up more than $60 \%$ of the total housing stock in the cities of the Fergana Valley. It is now more than 50 years since the first built-in specimens of these buildings were erected. The spiritual and physical obsolescence of these buildings is now approaching $-55-60 \%$. In another 10-15 years, this situation will become one of the main problems of the state housing fund. At the time of their construction, these buildings fully met the requirements of the Soviet era, but now they are becoming obsolete and do not meet the requirements of the times.

2- It is a big problem for the population of Uzbekistan, which is experiencing demographic development and is in great need of housing. The annual population growth in the country is 1.1-1.15 million. In 10 years (2030) the population of Uzbekistan will reach 50-51.5 million. At the current rate of 
development, the demand for housing is $1,650,000$ families per year, and on average $50-60 \%$ of them need additional housing. To prevent this, there is a need to build 250,000 300,000 families per year - 4,200-5,000 multistorey buildings per year for $600,000-700,000$ families. If we take into account the longstanding families, such buildings will be close to $5,500-6,000$.

3- Given the limited land resources in Uzbekistan, the construction of buildings of this size poses a major problem. When the attic floor is built, 2 additional apartments of 23 rooms in each section will be built in a full building, 6-apartment house in a 3-section building. The construction of such buildings on the 5 th floor in 2 levels (2-storey) is intended to ensure the interaction of people on the floors through the internal spiral staircase.

4- It is planned to lighten the roof of the building (metal-corrugated sheet) and the use of a pitched roof and the organized collection of atmospheric rain and snow water and the use of this water for the technical needs of the building. Currently, there are interruptions in the supply of water to buildings in cities there is a shortage of water. Water from atmospheric precipitation in early spring, autumn and winter is not used in practice, so the following is proposed.

5- Construction of the attic floor in the building. The most common shortcoming of the 72-series buildings is the interconnection of the roofing elements - as a result of imperfect production of chips.

As a result of the passage of rainwater from the roof of the building;

1- It is very inconvenient for the residents - it causes the living rooms in the building to cool down during the winter, which makes the building unusable. in addition to the use of gas appliances for heating rooms and excessive consumption of natural gas.

2- The water passing through the joints of the roofing tiles corrodes the metal-bonding parts connecting the reinforced concrete elements, which leads to premature failure and failure of building structures.

n conclusion, it is necessary to repair these buildings and reconstruct its roof. We consider it expedient to reconstruct the roof of the building and build another floor - attic.

6-Work can be done in the following sequence; -The roof attic of the building under repair is opened-ie;

1) - roofing-slab slabs and its supporting reinforced concrete elements and parapet slabs are dismantled and removed.

2) Glass fiber "mats" in the heat-protective layer of the roof are left - the expanded clay gravel is removed.

3) -4 reinforcement frames (A-II D-14) will be installed on the outer walls of the building and it will be welded to the wall details. .

4) -On the plate covering the 5 th floor of the building and a layer of heat-protective fiberglass; $\mathrm{H}=0.05 \mathrm{~m}$. expanded clay concrete is poured in the form of "screed" - that is, the floor is laid.

5) $-20 \times 20 \times 40 \mathrm{~cm}$ over seismic belt. walls are made of lightweight slag blocks of size and are reinforced with 3 rows of reinforcement wire (B-1 D-4).

6) - The height of the attic floor room - $\mathrm{H}=$ $2.5 \mathrm{~m}$. The roof of the attic floor is made of wooden beams. The interior and exterior decoration of the attic floor windows and doors, ceilings, floors, coverings - made of cheap modern lightweight materials. 
7) -The building will have a sloping roof, the roof will be supported by a sloping rafter, the outer parapet, and the roof will be made of tin sheets.

8) - Seismic belt-monolithic parapet with a height of $\mathrm{H}=2.7 \mathrm{~m}$ and $\mathrm{a}$ thickness of $\mathrm{B}=$ $0.4 \mathrm{~m}$ is made from the roof of the outer wall -5 th floor (assuming that it is $0.00 \mathrm{~m}$ from expanded clay concrete screed). And cross-section consists of the following parts-calculated from the inside of the building-cross-section;

- $\quad$ - b1 $=15 \mathrm{~cm}$. height of the load-bearing part, h1 $=30 \mathrm{~cm}$ from the wall.

- $\quad$ the part of the sloping trench of b2 = $10 \mathrm{~cm}$, the slope of which is formed $\mathrm{i}=$ 0.056 (at the longest distance $\mathrm{i}=$ 10/1800) for the flow of water along the length of the trench wall height $\mathrm{h} 2$ $=10 \mathrm{~cm}$ from the wall; $-\mathrm{s}$ ) $-\mathrm{b}_{3}=$ height of the wall section of $15 \mathrm{~cm} \mathrm{~h} 3=50 \mathrm{~cm}$ from the wall. consists of parts. The inside of the parapet is load-bearing.

This load-bearing part is designed to support the sloping beam of the roof of the building, and rainwater from the roof flows from the cladding tin to the parapet of the parapet in the middle. This water is poured into a special container on the cover of the stairwell and collects $V=3.0 \mathrm{~m} 3$, from which it flows through the pipe to the toilets of the 4.5storey building, through the valve to the washing tank (smyvnoy bachok). Water generated by atmospheric precipitation-rainsnow will be able to cover $30 \%$ of the technical water consumption of the building.

In the foothills of the country, this value can reach 50\%, which allows us to dramatically increase the energy efficiency of the building. The cost of the proposed reconstruction and modification will be covered in 5-6 years by the benefits from it, and they are as follows: provides cost-effectiveness;
1. -5 reconstructed buildings- 1 fully saved $5-$ storey building to save money and land area under construction.

2. -Reduce the consumption of drinking water by up to $30 \%$ for technical needs.

3. - It is at the expense of savings in the use of electricity to pump water upwards.

The total weight of the mansard device and lightweight roofing with the total weight of the roofing, parapet and load-bearing reinforced concrete elements of the building is $1: 1.05$, and this ratio remains approximately equal to the strength reserve of the building. In terms of seismicity, this building and its attic part - does not lose its resistance to 91 points. There will be no significant change in the weight of the building to the ground The foundation of the building can accept such loads in normal condition.

\section{REFERENCES}

1. Неелов В.М. “Архитектурные конструкции зданий” Москва.строй издат 1983 год

2. Орловиский Б.Я., Сербинович П.П. "Архитектура гражданских и промышленных зданий” Москва.строй издат 1978 год

3. Yousupov U.T. Akhmedov T.O. "Devolopment of polyfunctional additives based on sekondari resources andtechnologies of portland cement production" "International Journal of Researchculture Society" India (2019. 12. 12)

4. Xaydarov Abduxalil Mutalib Ogli, Development of effective cement additives for the production of heatresistant concrete based on technogenic waste "International Journal of Researchculture Society" India (2019. 12. 12)

5. Тешабаева Н.А."Исползование минеральных напольнителей ихимической добавки АЦФ; ПАВ; 
полуфункционального назначение при производстве цемента"

6. Mirzajonovich, Q. G., Ogli, A. U. A., \& Ogli, X. A. M. (2020). Influence of Hydro Phobizing Additives On Thermophysical Properties And LongTerm Life Of Keramzitobetona In An Aggressive Medium. The American Journal of Engineering and Technology, 2(11), 101-107.

7. Ogli, X. A. M., Ogli, A. U. A., \& Mirzajonovich, Q. G. (2020). Ways Of Implementation Of Environmental Emergency Situations In Engineering Preparation Works In Cities. The American Journal of Engineering and Technology, 2(11), 108-112.

8. Mirzaahmedov, A. T. (2020). Accounting For Non-Linear Work of Reinforced Concrete In The Algorithms Of Calculation And Design Of Structures. The American Journal of Engineering and Technology, 2(11), 5466.

9. Ogli, A. U. A., Ogli, X. A. M., \& Mirzajonovich, Q. G. (2020). Hazrati Imam Architecture The Complex Is A Holiday Of Our People. The American Journal of Engineering and Technology, 2(11), 46-49. 